МЕТОДИКА НАВЧАННЯ ПЕРЕКЛАДУ

УДК 371.315:811.111’255

\title{
ПСИХОЛОГІЧНА МОДЕЛЬ СТУДЕНТА - МАЙБУТНЬОГО ПИСЬМОВОГО ПЕРЕКЛАДАЧА
}

\author{
Стрілець В. В. \\ Київський наиіональний лінгвістичний університет \\ Полтавський національний технічний університет імені Юрія Кондратюка \\ vvctrilets@gmail.com \\ Дата надходження 18.11.2018. Рекомендовано до друку 20.12.2018.
}

\begin{abstract}
Анотація. У статті розглядається багатогранна психологічна модель студента - майбутнього письмового перекладача, яка включає мотиваційний, психофізіологічний, інтелектуальний, емоційний, предметнопрактичной, регулятивний, вольовий, екзистенціальний і соціально-комунікативний компоненти. Їхній зміст визначається особливостями перебігу письмового перекладу та специфікою майбутньої професійної діяльності. Зазначається, що в процесі навчання письмового перекладу викладачу необхідно враховувати мотиви, індивідуальні особливості й природні задатки студентів, а також створювати умови для розвитку й удосконалення психологічних механізмів перекладацької мовленнєвої діяльності та професійно вагомих особистісних якостей.

Ключові слова: психологічна модель, письмовий перекладач, мотивація, якості.
\end{abstract}

Стрилец В. В. Киевский национальный лингвистический университет, Полтавский национальный технический университет имени Юрия Кондратюка

Психологическая модель студента - будущего письменного переводчика

Аннотация. В статье рассматривается многогранная психологическая модель студента - будущего письменного переводчика, которая включает мотивационный, психофизиологический, интеллектуаальный, эмоциональный, предметно-практический, регулятивный, волевой, экзистенциальный и социальнокоммуникативный компоненты. Их содержание определяется особенностями процесса письменного перевода и спецификой будущей профессиональной деятельности. Отмечается, что в процессе обучения письменному переводу преподавателю необходимо учитывать мотивы, индивидуальные особенности и природные задатки студентов, а также создавать условия для развития и усовершенствования психологических механизмов переводческой речевой деятельности и профессионально важных личностных качеств.

Ключевые слова: психологическая модель, письменный переводчик, мотивация, качества.

Strilets V. V. Kyiv National Linguistic University, Poltava National Technical Yuri Kondratyuk University Psychological model of a prospective translator

Abstract. Introduction. According to the contemporary educational paradigm, prospective translators' training should be based on students' psychological characteristics projected on translator's professional qualities. Therefore, there must be created a prospective translator's psychological model comprising generalized qualities acquired by a professional translator for successful fulfilment of tasks arising in the job-related environment as well as for self-development and self-improvement. Purpose. To describe a prospective translator's psychological model from the perspective of essential professional qualities. Methods. Analysis of research findings in the areas of psychology, pedagogy and language teaching methodology. Results. Prospective translators' learning motivation is determined by cognitive, process-focused, esthetic, pragmatic and professional achievement motives. Psychophysiological mechanisms, involving comprehension (perception, understanding, attention), long-term and short-term memory, function in parallel with such mental processes as analysis, synthesis, comparison, association, reflection, and abduction. Emotional resilience, anxiety control, and empathy make up the emotional component 
of the model. Its subject-practical constituent implies referring a student to a particular psychological type: cognitive-lingustic / speech-communicative, and introvert / extravert. Regulatory (stress resilience, time management) and conative (determination, persistence, confidence, self-discipline) qualities are important for students' independent work and life-long learning. Existential component is associated with self-acceptance and personal freedom. Social-communicative constituent comprises team work and managerial skills. Conclusion. A translator trainer should take into account students' motives, individual qualities and abilities, as well as create favourable conditions for developing and improving psychological mechanisms of translation speech activity and essential professional qualities.

Key words: psychological model, translator, motivation, personal qualities.

Постановка проблеми. Соціальне замовлення на кваліфікованих письмових перекладачів, здатних надавати письмові перекладацькі послуги в різних галузях, висуває високі вимоги до професійної підготовки бакалаврів - майбутніх філологів, яка згідно із сучасною освітньою парадигмою має враховувати психологічні особливості студентів із проекцією на професійно вагомі якості письмового перекладача. Тому актуалізується питання створення психологічної моделі майбутнього перекладача, під якою ми, слідом за О. Б. Бігич, розуміємо сукупність узагальнених якостей, якими має володіти фахівець певного профілю для успішного вирішення всіх завдань, які виникають в умовах професійної діяльності, а також для саморозвитку й самовдосконалення $(2014$, с. 5).

Аналіз останніх досліджень і публікацій. Увагу науковців привертають різні аспекти особистості перекладача: психічні процеси, психолінгвістичні й когнітивні механізми, психологічні особливості, а також питання опертя на наявні й розвиток необхідних якостей у студентів майбутніх перекладачів. Л. О. Максименко (2015) проаналізувала специфіку психологічних механізмів мовленнєвої діяльності перекладача в письмовому перекладі, Л. П. Тарнаєва (2017) запропонувала своє бачення цієї проблеми, а також дослідила когнітивні механізми мовленнєвої діяльності перекладача (2008). Л. М. Черноватий (2013) дослідив особливості природного й штучного білінгвізму й охарактеризував особистісну компетенцію майбутнього перекладача. М. І. Прозорова (2006) виокремила професійно вагомі якості лінгвіста-перекладача, a О. В. Михайлов (2010) розробив структуру його професійного покликання. О. В. Костіна (2011) створила педагогічну модель формування особистісної свободи майбутніх лінгвістівперекладачів у процесі їхньої професійної підготовки. Ю. І. Матюшина (2010) розглянула особистість майбутнього перекладача крізь призму формування його професійного іміджу. Е. В. Васильєва (2014, сс. 109-116) охарактеризувала студента як активного суб'єкта учіння 3 формування перекладацької компетентності в контексті особистісно-діяльнісного підходу. Д. Робінсон (2007) розглянув майбутнього перекладача як творчу особистість. Л. А. Тархова (2006) проаналізувала умови для розвитку його пізнавальної самостійності. О. В. Старікова (2011) запропонувала методичну характеристику академічної групи в контексті диференційованого підходу до іншомовної підготовки перекладача. Проте всебічна характеристика майбутнього бакалавра філології, який навчається за освітньою програмою, спрямованою на галузевий переклад, і зорієнтований на письмову перекладацьку діяльність, не була належним чином представлена в наукових публікаціях.

Мета статті - описати психологічну модель студента - майбутнього письмового перекладача крізь призму його професійно вагомих якостей.

Основний матеріал дослідження. Традиційно в науково-методичній літературі психологічна структура індивідуальності розглядається згідно із запропонованими К. К. Платоновим (1986) 4-ма підструктурами: спрямованості, соціального досвіду, форм відображення і біологічних властивостей. Л. М. Черноватий $(2013$, с. 176) охарактеризував особистісну компетенцію майбутнього перекладача, спираючись на психофізіологічну, соціальну, морально-етичну субкомпетенції й субкомпетенцію самовдосконалення. О. В. Михайлов (2010) дослідив 
професійне покликання перекладача у межах ширшого спектру компонентів: когнітивного, емоційного, мотиваційного, вольового, практичного і духовно-морального. У науковому доробку Ю. В. Троїцької (2007, с. 69), сфокусованому на формування професійної мобільності перекладача мультимедійними засобами, особистість перекладача розглядається крізь призму ціннісномотиваційного, когнітивного, адаптивно-регулятивного, рефлексивно-аналітичного й комунікативного компонентів. Найповніше, на нашу думку, психологічну характеристику майбутнього фахівця - лінгвіста-перекладача представлено М. I. Прозоровою (2004; 2006), яка, спираючись на запропоновану О. С. Гребенюком і Т. Б. Гребенюк (2000, сc. 6-10) модель, виділила професійно вагомі якості лінгвіста-перекладача в межах мотиваційної, інтелектуальної, емоційної, регулятивної, вольової, предметно-практичної й екзистенціальної сфер. Оберемо підгрунтям цю структуру з такими модифікаціями: 1) враховуючи значущість для здійснення перекладу психофізіологічних механізмів, розмежуємо психофізіологічний та інтелектуальний складники, які авторка розглядала як одне ціле; 2) зважаючи на те, що основною професійною функцією сучасного письмового перекладача $€$ не просто виконання перекладу тексту, а надання перекладацьких послуг, додамо соціально-комунікативний складник, який співвідноситься 3 виділеною Л. М. Черноватим (2013, с. 176) соціальною субкомпетенцією. Охарактеризуємо зазначені компоненти психологічної моделі майбутнього письмового перекладача.

Учіння майбутнього письмового перекладача детермінується системою мотивів, яка спонукається передусім внутрішнім мотивом, коли пізнавальна потреба "зустрічається" 3 предметом діяльності й водночас стимулюється різноманітними зовнішніми мотивами, наприклад, самоствердження, престижності, обов'язку, необхідності, досягнення (Зимняя, 2005, c. 227). У процесі навчання письмового перекладу пізнавальна потреба реалізується через поглиблення перекладацької ерудиції (набуття фонових і предметних знань), а також засвоєння термінологічних одиниць певної галузі. При цьому, як зазначає Л. А. Тархова (2006, с. 59), позитивне ставлення майбутніх перекладачів до процесу пізнання досягається, коли створюються умови для їх особистісного самовираження й розкриття внутрішнього творчого потенціалу. Найбільший вплив на академічні успіхи має пізнавальна потреба в поєднанні з високою потребою в досягненнях (Орлов, Творогова и Шкуркин, 1988, с. 75). Для студента-майбутнього перекладача, особливо старшокурсника, академічне досягнення безпосередньо корелює з професійним досягненням, особливо за умови його залучення до виконання реальних перекладацьких проектів як в освітній, так і виробничій сферах.

I. О. Зимня зазначає, що рівень стійкості навчальної мотивації підвищується за умов домінування в мотиваційній структурі студента процесуального компонента (Зимняя, 2005, с. 230). Процесуальна мотивація виникає, коли виконувані студентом дії (використання способів, прийомів і стратегій письмового перекладу, а також застосуванням засобів інформаційнокомунікаційних технологій професійного призначення: електронних словників, баз даних, систем автоматизованого перекладу типу Trados i SmartCAT, систем машинного перекладу) набувають особистої значущості й дають йому змогу виявити себе й самоствердитись.

Розвиваючи ідею Д. Робінсона (Robinson, 2007, с. 36) про необхідність поступового ускладнення перекладацьких завдань і відповідних умінь задля уникнення рутинності навчального процесу, зазначимо, що моделювання умов, максимально наближених до реальної перекладацької діяльности, та залучення студентів до реальних перекладацьких проектів як у межах закладу вищої освіти (переклад матеріалів міжнародних конференцій, інформаційних листів, проспектів тощо), так і поза його межами (виконання замовлень для установ і підприємств) стимулюють як процесуальну мотивацію, так і мотивацію професійного досягнення.

Виконуючи письмовий переклад, студент повинен отримувати естетичне задоволення від процесу перекладу. Д. Робінсон порівнює письмового перекладача (навіть галузевих текстів) із письменником, який переживає миті насолоди творчості і прагне повторити ці відчуття 
знову (Robinson, 2007, с. 35). Ю. В. Троїцька зазначає, що для успішної професійної реалізації емоційна мотивація, пов'язана із захопленням перекладом / перекладацькою діяльністю, має доповнюватись прагматичною мотивацією, яка виражається в зацікавленості перспективами, що дає перекладацька освіта. Студентам важливо усвідомити, що гідна платня за перекладацькі послуги надається тим фахівцям, рівень професіоналізму яких відвідповідає вимогам замовника (Троицкая, 2017, с. 71).

Отже, навчальна мотивація майбутніх письмових перекладачів містить пізнавальний, процесуальний, естетичний і прагматичний компоненти, підкріплені мотивом професійного досягнення, які задля забезпечення академічної успішності студентів мають підтримуватися на високому рівні.

Письмовий переклад належить до специфічного рецептивно-репродуктивного / продуктивного посередницького виду мовленнєвої діяльності, тому, як і в інших видах мовленнєвої діяльності, в його основі лежать психофізіологічні механізми осмислення (сприйняття, розуміння, уваги), мнемічної організації мовленнєвої діяльності, випереджального аналізу й синтезу, які, проте, мають свою специфіку.

Запуск у мовній свідомості перекладача механізму осмислення починається із психічного процесу сприйняття, результатом якого є розуміння - когнітивний процес осягнення смислу (Тарнаева, 2017, с. 202). Перекладацькі сприйняття і розуміння мають свої особливості: відбувається гальмування власної інтелектуальної реакції на сприйняття; текст оригіналу розуміється в єдності його формально-змістових характеристик; для оптимізації перекладацького рішення образ змісту оригіналу довго утримується в оперативній пам'яті; текст перекладу розуміється з позицій реципієнта 3 метою адаптації смислової схеми тексту оригіналу (Наугольных, 2006, с. 14).

Вагомим психічним процесом механізму осмислення є увага - стан психологічної концентрації, зосередженості на якомусь об’єкті. Професійно значущими для майбутнього перекладача є такі якості уваги:

- обсяг - кількість сигналів чи асоціацій, які можуть зберігатись у центрі ясної свідомості, набуваючи домінувальнго характеру;

- стійкість - тривалість, із якою виділені увагою процеси можуть зберігати свій домінувальний характер;

- розподіл - можливість концентрації в двох і більше фокусах;

- здатність до переключення - свідоме й осмислене переміщення уваги з одного об'єкта на інший (Тарнаева, 2017, с. 203).

Від того, наскільки перекладач є уважним, наскільки він володіє названими якостями уваги, залежить, зокрема, виокремлення імпліцитної інформації та ії подальша трансляція. Ці якості піддаються тренуванню, що важливо враховувати під час організації навчальної діяльності. (Тарнаева, 2017, с. 203)

Для розуміння особливостей пам'яті перекладача актуальними є іï характеристики, які виділяються за критерієм тривалості зберігання досвіду. Необхідність постійної апеляції в процесі перекладу до наявних у ментальному арсеналі перекладача знань зумовлює активне функціонування довготривалої пам'яті, а потреба співвіднесення отриманих у процесі перекладу знань із уже наявними вимагає високої активності оперативної пам'яті (Тарнаева, 2017, с. 204).

Е. В. Васильєва (2014, с. 111) вказує на тісний зв'язок між механізмами уваги, сприйняття, пам'яті й мислення в добиранні та застосуванні релевантних прийомів перекладу.

Складні механізми, які лежать в основі письмового перекладу, вимагають високого ступеня інтелектуального розвитку, зокрема здатності до зіставлення, узагальнення, систематизування, аналізу, синтезу, критичного оцінювання інформації, побудови асоціативних зв 'язків. Діяльність письмового перекладача може набувати ретроспективного характеру, коли є можливість 
пригадування фактів і спостережень, пов'язаних з інформацією тексту джерела (Тарнаева, 2017 , с. 205), тому значна роль належить рефлексивному мисленню. Ю. І. Матюшина наголошує на значущості лінгвістичного інтелекту, який характеризує здатність до смислового запам'ятовування, концентрації й розподілу уваги; усвідомлення способу смислотворення і визначення контекстуального значення повідомлення; уміння конструювати смисл повідомлення; уміння аналізувати факти і ситуації (Матюшина, 2010, с. 11). До цієї категорії також належать така професійно вагома якість, як здатність до переключення з однієї мови на іншу.

Евристичний, творчий характер не тільки усної, а й письмової перекладацької діяльності вимагає пластичності й гнучкості мислення, які, згідно з Я. Б. Ємельяновою, передбачають здатність відійти від звичного бачення ситуації, прийняти / присвоїти “інший” погляд на світ, дивитися на речі з різних точок зору (Емельянова, 2015, с. 107). А. Г. Мінченков пояснює евристичну і творчу природу письмового перекладу через механізм такого типу логічного міркування, як абдукція - висування і спростування перекладачем гіпотез для знаходження оптимального перекладацького рішення (Минченков, 2008, с. 12).

Емоційний компонент охоплює такі характеристики, як емоційна стійкість, усвідомлення причини тривожності й уміння знижувати ії рівень. Остання якість важлива під час виконання завдань не тільки усного, як наголошує Л. М. Черноватий (2013, с. 71), але й письмового перекладу. Згідно $з$ дослідженням М. Козми і Д. Деджіка-Картса (Cozma, Dejica-Carts, 2013, с. 896), тривожність майбутніх перекладачів викликана побоюванням, що вони можуть опинитися в ситуації, яка виявить їхню недостатню обізнаність (у плані володіння предметними знаннями і термінологією) у певній галузі, тобто, що зміст навчання не відповідає умовам майбутньої професійної діяльності. Тому до змісту навчання необхідно залучати тексти тих галузей, які $€$ актуальними для конкретного регіону, а також уміння, які сьогодні вимагають роботодавці сфери перекладацьких послуг, що сприятиме також посиленню мотивації професійного досягнення.

Роль посередника в процесі міжкультурної комунікації посилює значущість для майбутнього перекладача емпатії, яку Я. Б. Смельянова характеризує як здатність і готовність поставити себе на місце іншої людини, щоб зрозуміти ії погляд на світ і логіку мислення; здатність емоційно відгукнутися на позицію представника іншої культури, його бачення світу; здатність (на певний час) відсунути свої звичні погляди і переконання на другий план (Емельянова, 2015, c. 107).

Предметно-практичний складник співвідноситься із лінгвістичними і перекладацькими здібностями. Науковці пропонують ураховувати індивідуальні психологічні особливості студента, зокрема його приналежність до комунікативно-мовленнєвого, когнітивно-лінгвістичного чи змішаного типу опанування видів мовленнєвої діяльності, включаючи переклад як ії особливий вид. Згідно з епмпіричними дослідженнями, проведеними Н. Я. Большуновою і О. В. Дьячковим, представники когнітивно-лінгвістичного (мисленнєвого) типу виконують письмовий переклад, орієнтуючись на морфологічні й граматичні ознаки мовних одиниць, слідуючи логікограматичним зв'язкам слів у реченнях і словосполученнях, намагаючись передати якомога точніше синтаксичну структуру речення; спираючись переважно на лінгвістичні прийоми. Представники комунікативно-мовленнєвого (художнього) типу намагаються передати ті відчуття і той емоційний фон, який у них склався під час сприйняття мовної конструкції, іноді нехтуючи лінгвістичними правилами обох мов, демонструючи орієнтацію на суб'єктивно значущу інформацію і використовуючи при цьому здебільшого екстралінгвістичні прийоми (Большунова, Дьячков, 2017, с. 162-163). За допомогою спеціально дібраних завдань викладач має підсилювати переваги певного типу, а з іншого боку, розвивати недостатньо представлені в майбутнього перекладача компоненти, властиві іншому мовному типу (Большунова, Дьячков, 2017, с. 163). 
Не менш важливим є визначення психологічного типу студента за критерієм “інтроверсія екстраверсія”. Так, згідно з Л. П. Тарнаєвою, письмовий переклад найчастіше вибирають ті перекладачі, які належать за своїм психологічним типом переважно до інтровертів, оскільки під час прийняття перекладацького рішення вони більше схильні до рефлексії, аналізу, перебирання варіантів (Тарнаева, 2017, с. 205).

Великі обсяги перекладацьких завдань і стислі терміни їх виконання потребують розвитку в майбутнього перекладача регулятивної сфери, яка передбачає його готовність діяти в екстремальних умовах, стійкість до інтенсивного розумового напруження, а також уміння регулювати й контролювати свій освітній / виробничий процес, організовувати своє робоче місце, ефективно розподіляти час, сили, дотримуватися термінів виконання.

Вольовий компонент психологічної структури майбутнього перекладача містить такі якості, як цілеспрямованість, наполегливість, рішучість, упевненість, організованість, самодисципліна, зібраність, здатність доводити розпочату справу (наприклад, перекладацький проект) до кінця.

М. І. Прозоровою встановлено, що у студентів-лінгвістів проявляється компенсація невисокого рівня розвитку професійно вагомих якостей емоційної й регулятивної сфер за рахунок належної сформованості якостей у предметно-практичній, вольовій і мотиваційній сферах (Прозорова, 2006, сс. 39-40).

Перераховані регулятивні й вольові якості $є$ вагомими для організації самостійної позааудиторної роботи студентів, адже письмовий переклад виконується переважно вдома. Вони необхідні для саморозвитку і самовдосконалення, які є не тільки особливістю сучасної освітньої парадигми, але й професійною вимогою до перекладача, який має розвиватись упродовж усього професійного життя: розширювати діапазон фонових і предметних знань; якщо виникла необхідність, працювати в новій галузі (медичній, юридичній, будівельній тощо); вдосконалювати інформаційно-технологічну компетенцію, опановуючи нові засоби інформаційнокомунікаційних технологій, тощо.

Процес письмового перекладу має човниковий характер, а його останньою фазою $\epsilon$ редагування, що потребує від перекладача вміння здійснювати самоаналіз і самооцінку як кінцевого продукту, так і процесу власної діяльності. Виконання ролі редактора, як це відбувається в професійному інформаційно-комунікаційному середовищі, створеному такими системами, як Trados, SmartCAT та їхніми аналогами, вимагає вміння здійснювати взаємні аналіз й оцінку.

Екзистенцііальний компонент асоціюється з адекватною самооцінкою на базі сформованої Я-концепції (Матюшина, 2010, с. 13), усвідомленням Я-позицій під час взаємодії з учасниками міжкультурного спілкування (Прозорова, 2004, с. 9). Ці якості розвиваються шляхом “створення для студентів можливості обстоювати свої погляди, цілі, життєві позиції в процесі навчальнопізнавальної роботи” (Зимняя, 2005, с. 180). О. В. Костіна підкреслює необхідність формування особистісної свободи майбутнього перекладача, характеристиками якої $є$ критичність мислення; відкритість і невимушеність у взаємодії з іншими людьми; самовизначення в діяльності на основі зіставлення цінностей і передбачених наслідків, а також прийняття на себе відповідальності за здійснений вибір (Костина, 2011, с. 9). Із запропонованих дослідницею показників сформованості особистісної свободи виділимо такі: на когнітивному рівні - усвідомлення особистісного характеру свободи, взвємозв'язку свободи з відповідальністю, відмінності свободи від вседозволеності, ролі свободи в творчій самореалізації перекладача; на емоційноціннісному рівні - орієнтація в діяльності й поведінці на власні переконання й систему цінностей; на діяльнісному рівні - самостійність й осмисленість в оволодінні іноземними мовами, вміння будувати програму саморозвитку особистісної свободи (Костина, 2011, с. 10).

Специфіка надання письмових перекладацьких послуг у сучасних умовах визначає зміст соціально-комунікативного складника психологічної моделі студента - майбутнього 
перекладача, який, як зазначає Л. М. Черноватий, повинен знати прийоми й норми спілкування в професійному середовищі, вміти пропонувати свої послуги на ринку праці, укладати договір на виконання перекладу, співпрацювати з фахівцями у відповідній галузі (Черноватий, 2013, с. 176). Крім того, виконання різних професійних ролей - перекладача, редактора, менеджера перекладацького проекту - передбачає формування відповідних соціально-комунікативних умінь, зокрема, під час виконання останньої з перерахованих ролей - чітко окреслювати завдання й вимоги до його виконання, розподіляти обов'язки, здійснювати моніторинг роботи перекладацької команди.

Висновки і перспективи подальших наукових розвідок. Таким чином, психологічна модель студента - майбутнього письмового перекладача - охоплює такі аспекти психологічної структури особистості як мотиваційний, психофізіологічний, інтелектуальний, емоційний, предметно-практичной, регулятивний, вольовий, екзистенціальний і соціально-комунікативний, зміст яких визначається специфікою його майбутньої професійної діяльності. В процесі навчання письмового перекладу викладач має враховувати мотиви, індивідуальні особливості й природні задатки студентів, а також створювати умови для розвитку й удосконалення психологічних механізмів перекладацької мовленнєвої діяльності та професійно вагомих особистісних якостей.

Описана в цій статті модель студента допоможе окреслити принципи, підходи й технології формування у майбутніх бакалаврів філології компетентності в письмовому, зокрема науковотехнічному перекладі, що становить перспективу подальших наукових розвідок.

\section{ЛІТЕРАТУРА}

Бігич, О. Б., Васильєва, Е. В., Волошинова, М. М., Глазунов, М. С., Майєр, Н. В., Мацнєва, О. А., ... Ярошенко, О. В. (2014). Сучасний студент у контексті особистісно-діяльнісного nідходу: за результатами науково-методичних досліджень [колективна монографія]. Київ, Україна: Вид. центр КНЛУ.

Большунова, Н. Я. и Дьячков, А. В. (2017). Индивидуально-психологические особенности перевода как составляющие языковых способностей. Вестник РУДН. Серия: Психология и педагогика. Т. 14, 2, 155-166.

Гребенюк, О. С. и Гребенюк Т. Б. (2000). Основы педагогики индивидуальности. Калининград, Российская Федерация: Изд-во КГУ,

Емельянова Я. Б. (2015). Характеристика переключнения кода в коммуникации с переводом. Вестник ВГУ. Серия: Лингвистика и межкультурная коммуникация. 4, 105-109.

Зимняя, И. А. (2005). Педагогическая психология. Москва, Российская Федерация: Логос.

Костина, О. В. (2011). Формирование личностной свободы будущих лингвистов-переводчиков в процессе профессиональной подготовки в вузе (Автореферат кандидатской диссертации). Вятский государственный гуманитарный университет, Киров, Российская Федерация.

Матюшина, Ю. И. (2010). Формирование профессионального имиджа у будущего переводчика (Автореферат кандидатской диссертации). Российский государственный университет имени Иммануила Канта, Калининград, Российская Федерация.

Максименко, Л. О. (2015). Специфіка психологічних механізмів мовленнєвої діяльності перекладача у письмовому двосторонньому перекладі. Вісник КНЛУ. Серія Педагогіка та психологія. 24, 25-37.

Минченков, А. Г. (2008). Когнитивно-эвристическая модель перевода (на материале английского языка) (Автореферат докторской диссертации). Санкт-Петербургский государственный университет, Санкт-Петербург, Российская Федерация.

Михайлов, А. В. (2010). Формирование профессионального призвания будущего переводчика (Автореферат кандидатской диссертации). Российский государственный университет имени Иммануила Канта, Калининград, Российская Федерация. 
Наугольных, А. Ю. (2006). Навыки и умения осмысления и понимания в полном письменном переводе как дидактический объект профессиональной подготовки переводчика (Автореферат кандидатской диссертации). Уральский государственный педагогический университет, Екатеринбург, Российская Федерация.

Орлов, Ю. М. Творогова, Н. Д. и Шкуркин В. И. (1988). Стимулирование побуждения к учению. Москва, Российская Федерация.

Платонов К. К. (1986). Структура и развитие личности. Москва, Российская Федерация: Наука. Прозорова, М. И. (2004). Формирование профессионально важных качеств переводчика у студентов-лингвистов в процессе обучения в вузе (Автореферат кандидатской диссертации). Калининградский государственный университет, Калининград, Российская Федерация.

Прозорова, М. И. (2006). Профессионально важные качества лингвиста-переводчика и педагогические средства их формирования. Вестник РГУ им. И. Канта. Филологические науки. 2, 36-41.

Старикова, О. В. (2011). Методика реализации дифференщированного подхода в иноязычном образовании переводчиков на основе применения программно-педагогического средства (Автореферат кандидатской диссертации). Московский государственный гуманитарный университет им. М. А. Шолохова, Москва, Российская Федерация.

Тарнаева, Л. П. (2017). Психологические механизмы речевой деятельности переводчика: лингводидактический аспект проблемы. Филологические науки. Вопросы теории и практики, 6 (72), Ч. 2, 202-205. Взято из: www.gramota.net/materials/2/2017/6-2/61.html.

Тарнаева, Л. П. (2008). Специфика когнитивных механизмов речевой деятельности переводчика: лингводидактический аспект. Вопросы современной науки и практики. Гуманитарные науки. 4 (14). Взято из: http://vernadsky.tstu.ru/pdf/2008/04g/09g_14.pdf

Тархова, Л. А. (2006). Формування пізнавальної самостійності майбутніх перекладачів у прочесі nрофесійної niдготовки (Кандидатська дисертація). Південноукраїнський державний педагогічний університет імені К. Д. Ушинського, Одеса, Україна.

Троицкая, Ю. В. (2017). Формирование профессиональной мобильности переводчиков мультимедийными средствами (Кандидатская диссертация). Самарский национальный исследовательский университет имени академика С. П. Королева, Самара, Российская Федерация.

Черноватий, Л. М. (2013). Методика викладання перекладу як спечіальності: підручник для студ. вищих заклад. освіти за спеціальністю “Переклад”. Вінниця: Нова книга.

Cozma, M. \& Dejica-Carts, D. (2013). Psychological approach to professional Translator Education. Procedia - Social and Behavioral Sciences. 84, 895-899.

Robinson, D. (2007). Becoming a translator. New York: Routledge.

\section{REFERENCES}

Bihych, O. B., Vasylieva, E. V., Voloshynova, M. M., Hlazunov, M. S., Maiier, N. V., Matsnieva, O. A., ... Yaroshenko, O. V. (2014). Suchasnyi student u konteksti osobystisno-diialnisnoho pidkhodu: za rezultatamy naukovo-metodychnykh doslidzhen [kolektyvna monohrafiia]. Kyiv, Ukraina: Vyd. tsentr KNLU.

Bol'shunova, N. Ja. i D'jachkov, A. V. (2017). Individual'no-psihologicheskie osobennosti perevoda kak sostavljajushhie jazykovyh sposobnostej. Vestnik RUDN. Serija: Psihologija i pedagogika, $14,2,155-166$

Grebenyuk, O. S. i Grebenyuk T. B. (2000). Osnovy pedagogiki individual'nosti: Uchebnoe posobie. Kaliningrad, Rossiyskaya Federatsiya: Izd-vo KGU,

Emel'yanova Ya. B. (2015). Kharakteristika pereklyuchneniya koda v kommunikatsii s perevodom. Vestnik VGU. Seriya: Lingvistika i mezhkul'turnaya kommunikatsiya. 4, 105-109.

Zimnyaya, I. A. (2005). Pedagogicheskaya psikhologiya: Uchebnik dlya vuzov. Moskva, Rossiyskaya Federatsiya: Logos. 
Kostina, O. V. (2011). Formirovanie lichnostnoy svobody budushchikh lingvistov-perevodchikov $v$ protsesse professional'noy podgotovki v vuze (Avtoreferat kandidatskoy dissertatsii). Vyatskiy gosudarstvennyy gumanitarnyy universitet, Kirov, Rossiyskaya Federatsiya.

Matyushina, Yu. I. (2010). Formirovanie professional'nogo imidzha u budushchego perevodchika (Avtoreferat kandidatskoy dissertatsii). Rossiyskiy gosudarstvennyy universitet imeni Immanuila Kanta, Kaliningrad, Rossiyskaya Federatsiya.

Maksymenko, L. O. (2015). Spetsyfika psykholohichnykh mekhanizmiv movlennievoi diialnosti perekladacha u pysmovomu dvostoronnomu perekladi. Visnyk KNLU. Seriia Pedahohika ta psykholohiia. 24, 25-37.

Minchenkov, A. G. (2008). Kognitivno-evristicheskaya model' perevoda (na materiale angliyskogo yazyka) (Avtoreferat doktorskoy dissertatsii). Sankt-Peterburgskiy gosudarstvennyy universitet, Sankt-Peterburg, Rossiyskaya Federatsiya.

Mikhaylov, A. V. (2010). Formirovanie professional'nogo prizvaniya budushchego perevodchika (Avtoreferat kandidatskoy dissertatsii). Rossiyskiy gosudarstvennyy universitet imeni Immanuila Kanta, Kaliningrad, Rossiyskaya Federatsiya.

Naugol'nykh, A. Yu. (2006). Navyki i umeniya osmysleniya i ponimaniya $v$ polnom pis'mennom perevode kak didakticheskiy ob"ekt professional'noy podgotovki perevodchika (Avtoreferat kandidatskoy dissertatsii). Ural'skiy gosudarstvennyy pedagogicheskiy universitet, Ekaterinburg, Rossiyskaya Federatsiya.

Orlov, Yu. M. Tvorogova, N. D. i Shkurkin V. I. (1988). Stimulirovanie pobuzhdeniya k ucheniyu. Moskva, Rossiyskaya Federatsiya.

Platonov K. K. (1986). Struktura i razvitie lichnosti. Moskva, Rossiyskaya Federatsiya: Nauka.

Prozorova, M. I. (2004). Formirovanie professional'no vazhnykh kachestv perevodchika u studentovlingvistov v protsesse obucheniya $v$ vuze (Avtoreferat kandidatskoy dissertatsii). Kaliningradskiy gosudarstvennyy universitet, Kaliningrad, Rossiyskaya Federatsiya.

Prozorova, M. I. (2006). Professional'no vazhnye kachestva lingvista-perevodchika i pedagogicheskie sredstva ikh formirovaniya. Vestnik RGU im. I. Kanta. Filologicheskie nauki. 2, 36-41.

Starikova, O. V. (2011). Metodika realizatsii differentsirovannogo podkhoda $v$ inoyazychnom obrazovanii perevodchikov na osnove primeneniya programmno-pedagogicheskogo sredstva (Avtoreferat kandidatskoy dissertatsii). Moskovskiy gosudarstvennyy gumanitarnyy universitet im. M. A. Sholokhova, Moskva, Rossiyskaya Federatsiya.

Tarnaeva, L. P. (2017). Psikhologicheskie mekhanizmy rechevoy deyatel'nosti perevodchika: lingvodidakticheskiy aspekt problemy. Filologicheskie nauki. Voprosy teorii i praktiki, 6 (72), Ch. 2, 202-205. Vzyato iz: www.gramota.net/materials/2/2017/6-2/61.html.

Tarnaeva, L. P. (2008). Spetsifika kognitivnykh mekhanizmov rechevoy deyatel'nosti perevodchika: lingvodidakticheskiy aspekt. Voprosy sovremennoy nauki i praktiki. Gumanitarnye nauki. 4 (14). Vzyato iz: http://vernadsky.tstu.ru/pdf/2008/04g/09g_14.pdf

Tarkhova, L. A. (2006). Formuvannia piznavalnoi samostiinosti maibutnikh perekladachiv u protsesi profesiinoi pidhotovky (Kandydatska dysertatsiia). Pivdennoukrainskyi derzhavnyi pedahohichnyi universytet imeni K. D. Ushynskoho, Odesa, Ukraina.

Troitskaya, Yu. V. (2017). Formirovanie professional'noy mobil'nosti perevodchikov mul'timediynymi sredstvami (Kandidatskaya dissertatsiya). Samarskiy natsional'nyy issledovatel'skiy universitet imeni akademika S. P. Koroleva, Samara, Rossiyskaya Federatsiya.

Chernovatyi, L. M. (2013). Metodyka vykladannia perekladu yak spetsialnosti: pidruchnyk dia stud. vyshchykh zaklad. osvity za spetsialnistiu "Pereklad". Vinnytsia: Nova knyha.

Cozma, M. \& Dejica-Carts, D. (2013). Psychological approach to professional Translator Education. Procedia - Social and Behavioral Sciences. 84, 895-899.

Robinson, D. (2007). Becoming a translator. New York: Routledge. 